\title{
Hypomagnesaemia with secondary hypocalcaemia due to TRPM6 gene mutation
}

\author{
Rajesh Joshi ${ }^{1}$, Phatarpekar Ankur ${ }^{2}$ \\ Sri Lanka Journal of Child Health, 2012; 41(4): 205-206
}

(Key Words: Hypomagnesaemia; TRPM6; convulsions)

\section{Introduction}

Hypomagnesaemia with secondary hypocalcaemia (HSH) is a rare autosomal recessive disease caused by mutation in a gene located on chromosome $9 q 22$ called TRPM6 gene ${ }^{1}$. We report a child with $\mathrm{HSH}$ presenting with intractable seizures which were controlled by giving magnesium.

\section{Case report}

A 9 month old boy born of a consanguineous union presented with multiple episodes of generalized tonic clonic convulsions for one month. He was treated with intravenous calcium gluconate and oral calcium supplements for hypocalcaemia [serum calcium $3.9 \mathrm{mg} / \mathrm{dl}$, serum phosphorous $9.5 \mathrm{mg} / \mathrm{dl}$, simultaneous parathyroid hormone (PTH) level $15.2 \mathrm{pg} / \mathrm{ml}$ (normal 12-95)] before referring to our hospital. He was also given intramuscular magnesium sulphate for five days without documenting a serum magnesium level. In spite of this treatment the patient kept on having convulsions.

The physical examination was normal. Investigations at our hospital revealed high serum phosphorous $(10.8 \mathrm{mg} / \mathrm{dl})$, normal alkaline phosphatase (257IU/1) and PTH level inappropriately low $(19.4 \mathrm{pg} / \mathrm{ml})$ for hypocalcaemia (serum calcium $7.2 \mathrm{mg} / \mathrm{dl}$ ). Serum electrolytes, blood gas analysis, serum 25 hydroxyvitaminD level and urine calcium/creatinine ratio were normal. Serum magnesium level on admission was $3.2 \mathrm{mg} / \mathrm{dl}$ (normal 1.8-2.4). With a provisional diagnosis of hypoparathyroidism, patient was treated with calcitriol and oral calcium of $0.5 \mu \mathrm{g}$ and $100 \mathrm{mg} / \mathrm{kg} /$ day which was gradually increased to $2 \mu \mathrm{g}$ and $115 \mathrm{mg} / \mathrm{kg}$ /day respectively because of persistent hypocalcaemia and intermittent seizures. We then repeated the serum magnesium levels, 22 and 25 days after the initial magnesium report and these were $2 \mathrm{mg} / \mathrm{dl}$ and $1.4 \mathrm{mg} / \mathrm{dl}$ (low). Fractional

\footnotetext{
${ }^{1}$ Associate Professor, ${ }^{2}$ Registrar, Department of Paediatrics, B. J. Wadia Hospital for Children, Parel, Mumbai, India
}

(Received on 7 February 2012; Accepted on 23 March 2012) excretion of magnesium $\left(\mathrm{FeMg}^{++}\right)$was $11.2 \%$ (normal up to 4\%). A diagnosis of hypomagnesaemia due to renal magnesium wasting was made. Patient was treated with intramuscular magnesium initially and then with oral magnesium carbonate at $40 \mathrm{mg} / \mathrm{kg} /$ day after which the serum calcium level normalized (serum calcium 9.1 $\mathrm{mg} / \mathrm{dl}$ ). Calcitriol and calcium were then tapered and stopped. Patient did not experience any further episodes of convulsions. On follow up, serum calcium and magnesium levels were done and found to be low or low normal, on an oral magnesium dose ranging from $25-80 \mathrm{mg} / \mathrm{kg} /$ day. A diagnosis of $\mathrm{HSH}$ was suspected and a mutation analysis was performed on blood. Genomic DNA was isolated. The gene encoding TRPM6 was amplified by PCR and the purified product sequenced by automated DNA sequencer. There was a missense mutation at p.T2L at exon 1 and silent mutation at exon 8F (p.G313G), 16F (p.A619A), 19F (p.Q809Q). The patient is now $3 \frac{1}{2}$ years old and has normal growth and milestones.

\section{Discussion}

$\mathrm{HSH}$, first described by Paunier et al in 1968 is characterised by extremely low levels of serum magnesium accompanied by hypocalcaemia. Hypocalcaemia results from an inhibition of PTH synthesis, its release from parathyroid gland and target organ resistance to $\mathrm{PTH}^{2}$. It typically manifests during the first months of life with convulsions, muscle spasms or tetany. Relief of symptoms is achieved by administration of intravenous or intramuscular magnesium followed by life-long treatment with high-dose oral magnesium $^{3}$. If an early diagnosis cannot be made or the treatment is started late, these convulsions can be fatal or may result in neurological sequelae ${ }^{3}$. In the present patient, there was a consanguineous marriage. However the parents had normal magnesium and calcium levels. Our patient, who presented with recurrent and prolonged seizures, was initially diagnosed with primary hypocalcaemia and was treated as such. Similar to most reported cases in the literature ${ }^{4}$, the failure to respond to calcium treatment led to the consideration of magnesium deficiency. After admission our patient had hypocalcaemic convulsions in spite of slightly high serum 
magnesium level, possibly due to empiric intramuscular magnesium treatment given by the referring physician. Hypocalcaemia may be due to intracellular magnesium depletion, where the major physiologic role of magnesium occurs as there is slow equilibrium between the serum and intracellular magnesium after treating with magnesium ${ }^{5}$. Mean oral magnesium requirement in one multicentre study ${ }^{3}$ done on HSH patients was found to be $0.93 \mathrm{mmol} / \mathrm{kg} /$ day $(22.8 \mathrm{mg} / \mathrm{kg} /$ day $)$ with a range of $0.41-3.9 \mathrm{mmol} / \mathrm{kg} /$ day (10$96 \mathrm{mg} / \mathrm{kg} /$ day).Serum magnesium usually fails to reach normal values under oral substitution therapy ${ }^{3}$, as seen in our patient. The main side effect of oral magnesium supplementation is diarrhoea which may require additional intramuscular injections.

TRPM6 gene encodes the TRPM6 protein which belongs to the melastatic related group of a large family of transient receptor potential (TRP) cation channels. It plays an important role in a wide variety of physiological processes, ranging from thermal, tactile, taste to transepithelial $\mathrm{Ca}^{++}$and $\mathrm{Mg}^{++}$transport ${ }^{6}$. Electrophysiological analysis and expression studies have demonstrated that TRPM6 confines a $\mathrm{Mg}^{++}$- permeable channel, which is specifically localised to the apical membrane of $\mathrm{Mg}^{++}$- reabsorbing tubules in the kidney (DCT) and the brush border membrane of the $\mathrm{Mg}^{++}$absorptive cells in the small intestine ${ }^{7}$. Majority of mutations found in HSH patients introduce stop codons, deletions of exons and frameshifts or affect splice sites, thus resulting in a complete loss of function of TRPM6 protein $^{3}$. These cause the combination of impaired gut reabsorption of magnesium and renal wasting in $\mathrm{HSH}$. In our patient $\mathrm{FeMg}^{++}$was high (renal wasting). However stool excretion of magnesium could not be done.

We report this case to sensitise the clinician towards this rare disease, since any delay in diagnosis may cause adverse neurodevelopmental outcome and sometimes may be fatal, the early treatment being very important for prognosis.

\section{Acknowledgement}

We thank Dr Dhananjit Das, Research Officer, Genetic Research centre, NIRRH, ICMR, Mumbai for helping in the molecular genetic analysis of the patient. We are grateful to Dr Y.K. Amdekar, Medical Director, B.J. Wadia Hospital for Children for allowing us to present this case report.

\section{References}

1. Walder RY, Shalev H, Brennan TM, Carmi R, Elbedour K, Scott DA, et al. Familial hypomagnesaemia maps to chromosome 9q, not to the $\mathrm{X}$ chromosome: genetic linkage mapping and analysis of a balanced translocation breakpoint. Human Molecular Genetics 1997; 6(9): 1491-7. http://dx.doi.org/10.1093/hmg/6.9.1491

2. Naderi AS, Reilly RF Jr. Hereditary aetiologies of hypomagnesaemia. Nature Clinical Practice Nephrology 2008; 4(2): 80-9. http://dx.doi.org/10.1038/ncpneph0680

3. Schlingmann KP, Sassen MC, Weber S, Penchmann U, Kusch K, Pelken L, et al. Novel TRPM6 mutations in 21 families with primary hypomagnesaemia and secondary hypocalcaemia. Journal of the American Society of Nephrology 2005; 16(10): 3061-9. http://dx.doi.org/10.1681/ASN.2004110989

4. Abdulrazzak YM, Smigura FC, Wettrell G. Primary infantile hypomagnesaemia; report of two cases and review of literature. European Journal of Pediatrics 1989; 148: 459-6. http://dx.doi.org/10.1007/BF00595914

5. Al-Gamdi SM, Cameron EC, Sutton RA. Magnesium deficiency: Pathophysiologic and clinical overview. American Journal of Kidney Diseases 1994; 24(5): 737-52.

6. Clapham DE. TRP channels as cellular sensors. Nature 2003; 426: 517-24. http://dx.doi.org/10.1038/nature02196

7. Voets T, Nilius B, Hoefs S, Van der Kemp AW, Droogmans G, Bindels RJ, et al. TRPM6 forms the $\mathrm{Mg}^{++}$influx channel involved in intestinal and renal $\mathrm{Mg}^{++}$absorption. Journal of Biological Chemistry 2004; 279: 19-25. http://dx.doi.org/10.1074/jbc.M311201200 